\title{
Acute Toxicity of Paraquat Dichloride on Blood Plasma Indices of Clarias gariepinus
}

\author{
*E.I. Seiyaboh, I.R. Inyang A.H. Gijo and G.D. Adobeni \\ Department of Biological Sciences, Niger Delta University, Wilberforce Island,P. M. B. 71, Yenagoa, Bayelsa \\ State, Nigeria.
}

\begin{abstract}
A comparative study of the acute toxicity of paraquat dichloride on blood plasma indices of Clarias gariepinus was carried out using thirty eight (38) adult fishes of Clarias gariepinus (mean weight 166 $54.13 \mathrm{~g}$; length $36.25 \pm 2.90 \mathrm{~cm}$ ) which were exposed to acute levels of paraquat dichloride (an organophosphate pesticide). The fishes were carefully netted to minimize stress and the area was wiped dry to avoid contamination. Blood was drawn from the heart with a $2 \mathrm{~cm} 3$ heparnized plastic syringed fitted with $23 G$ needle. The blood thus collected was preserved in EDTA bottles. The changes observed in haemoglobin. PCV, WBC and platelets showed a direct relationship with the exposed concentrations. Values increased with increasing concentration of the toxicant. The results clearly show profound effect of paraquat dichloride on energy metabolism, hence negative effect on blood plasma activities of Clarias gariepinus.
\end{abstract}

\section{Introduction}

Pesticides are primarily used to prevent, control or eliminate pests and man has beneftted much by the increased yield from agricultural products. Despite its role in enhanced yields, pesticides have been reported to have negative ecological consequences on the environment. Pesticides applied in field or from carless discarding of pesticide containers finally find their way into the aquatic environment, either through water runoff and or as aerosols carried by winds. The presence of pesticides in water bodies most often result in alteration of the physico-chemical properties of water (Richardson, 1988). Heavy contamination of water by pesticides in turn leads to oxygen depletion; poisoning and resultant mass mortality of fishes has been reported (Atamanalp, et. al., 2001).

The problems associated with pesticides are that they are often non-specific and may therefore be toxic to organisms that are not pests; they may also be non biodegradable, so they persist in the environment (Bus, et. al., 1983).

Paraquat is an organic herbicide used to control broad leaved weeds and grasses. It is poisonous to humans, having toxic effect on the liver, lungs and kidneys if ingested. Paraquat is easily broken down and can persist in the environment absorbed to soil particles (Elizabeth, 2000). Paraquat is a trade name for N,Ndimethyl 4, 4-bipyridinium dichloride, one of the most widely used herbicides in the world. Paraquat is quick acting and non-selective, killing green plant tissues on contact. It is also toxic to human beings when swallowed. In acute toxicity studies using laboratory animal's paraquat has been shown to be highly toxic by the inhibition route and has been placed in toxicity category. The acute toxicity of paraquat dichloride to fresh water fish species showed moderate sensitivity (Mayer and Ellersieck, 1986). By the dermal route, paraquat will cause moderate to severe eye irritation in man and has been placed in toxicity list.

The genus Clarias are unique in the ability to survive a wide variety of environmental extremes (Akiri, 1987). They have high efficient air breathing organs which allow them to survive in oxygen depleted water (Jordan, 1976). Clarias species are able to survive salinity increase for up to 25\% (Cherviniski, 1982; 1984), excessive crowding and rigours of transport stress (Haffingh. et al., 1975; Anthonio and Isoun, 1982). Clarias Spp survive in habitats where few or no other fishes can (Roberts, 1975) and have proved a serious threat to native populations in areas where they have been introduced because of their superior adaptability (Courtenary, 1979).

Clarias garipinus has fast growth rate in the natural and cultured environments (Reed, et al 1979 and has proved to be successful aquaculture species (Baradach. et al., 1972: Bruton, 1979; Hogandoorn, 1983).

\section{[1]Experimental Procedure}

\section{Materials \& Method}

Thirty-eight adult Clarias griepinus (mean weight $166 \pm 54.13 \mathrm{~g}$, mean length $36.25 \pm 2.90 \mathrm{~cm}$ ) were obtained from a private fish farm in Port Harcourt, Rivers State. They were transported to the department of biological sciences, Niger Delta University. On arrival the fishes were acclimated individually in rectangular aquaria for seven days, the top of the aquaria were covered to control escape of fish. The net had a slit at the 
middle for cleaning the aquaria. The water was changed daily and the aquaria washed with a piece of foam. The fishes were fed once a day with a $35 \%$ crude protein diet at $1 \%$ biomass daily $(09.00-10.00$ hours $)$.

A range finding text (trial test) was carried out using the toxicant paraquat dichloride, five concentrations of paraquat dichloride were prepared from the original solution $(350 \mathrm{~g} / \mathrm{c})$ using the formula;

N1 V2 = N2V2 (Grinshaw, 1978)

$\mathrm{N} 1$ = Manufacturer concentrated $(350 \mathrm{~g} / \mathrm{l})$

$\mathrm{N} 2=$ Concentration of test solution desired.

$\mathrm{V} 1=$ Volume of the original solution added.

$\mathrm{V} 2=$ Volume of the test solution (30 litre).

The test trial concentrations were $0.01 \mathrm{ppm}, 0.10 \mathrm{ppm}, 0.20 \mathrm{ppm}, 0.30 \mathrm{ppm}, 0.40 \mathrm{ppm}$ and $0.50 \mathrm{ppm}$. Three fishes were exposed to each concentration of paraquats dichloride. The introduction of the toxicant was done with the aid of pipette and suckers. The water was changed daily and the aquarium was washed with a piece of foam. The test solution was renewed daily immediately as in the acclimation period of seven days. The purpose of the test was to determine the range of concentration to be used for the definitive (main) test.

The sub-lethal concentration for the definitive test was done based on the range finding test. The concentration were prepared by pipetting $0.01 \mathrm{ml} / 1,0.02 \mathrm{ml} / 1,0.03 \mathrm{ml} / 1,0.04 \mathrm{ml} / 1,0.05 \mathrm{ml} / 1$ and $0.06 \mathrm{ml} / 1$ respectively of the original concentration of the paraquat dichloride $(350 \mathrm{~g} / \mathrm{l})$ and making it up to 30 litre with bore hole water in the aquaria to make $0.05 \mathrm{ppm}, 0.1 \mathrm{ppm}, 0.2 \mathrm{ppm}, 0.3 \mathrm{ppm}$ and $0.4 \mathrm{ppm}$. There were six treatment levels with three replicates. Three fishes were introduced individually into each aquarium containing the various concentration of the toxicant for a period of 30 days. 30litres of solution was used and fishes were fed as in the acclimatisaton period. The test solution was renewed daily after washing the aquarium. The water was filled to 25 litre point before the introduction of the toxicant, after which they were made up to the 30litres mark. Blood samples were collected from the fishes (behind the anal fin) with $23 \mathrm{~g}$ size needle and syringe for haematological studies; samples were preserved in EDTA bottles.

\section{[2]Physico-Chemical Parameters of Water}

The following physic-chemical parameters were measured on daily basis - Alkalinity, Conductivity, Salinity, $\mathrm{pH}$, Turbidity and Dissolved oxygen. The procedure for the analysis of these parameters was as described by APHA, (2011).

\section{[3]Haematological Studies}

Standard haematological procedures described by Blaxhall and Daisley (1973) were employed in the determination of the various blood parameters.

\section{[4] Analysis of Data}

The data were subjected to Analysis of Varience (ANOVA). Where differences exist, Ducan Multiple Range Test $(\mathrm{DMRT})$ were used to test for pair-wise significant difference $(\mathrm{P}<0.05)$ between treatments $($ Wahua, 1999)

\section{Result \& Discussion}

The results of the physico-chemical parameters of the exposed Concentration of Paraquat dichloride are presented in Table 1. The results of the haematological responses of Clarias gariepinus exposed to various concentrations of paraquat dichloride are presented in Table 2.

The water quality parameters did not differ from the control $(\mathrm{P}<0.05)$ except for a slight fall in value of $\mathrm{pH}$ and dissolved oxygen (DO). This result is in consonance with the work of Onusiriuke and Ufodike (1994) who exposed Clarias gariepinus to Akee apple and savage plant extracts and reported no significant difference $(\mathrm{P}<0.05)$ in the water quality parameters analyzed. All the values were within the suggested tolerance ranges of warm water fish species (Boyd, 1979; Adeniji and Orie, 1998). These parameters may not have caused significant abnormal behavioural changes in adult fish in this study.

There was general fluctuation in values of haematological parameters. LYM and WBC had slight elevation in value while haemoglobin, PCV, Neutrophilis, Platelets and ESR decreased with increase in the concentration of the toxicant. There was no significant difference between the experimental groups and the control values of platelets (thrombocyte). WBC elevation was recorded at $0.30 \mathrm{ppm}, 0.40 \mathrm{ppm}$ and $0.50 \mathrm{ppm}$. The highest value was recorded at $0.20 \mathrm{ppm}(104 \pm 0.00 \mathrm{SD})$. Haemoglobin suffered the most compared to other parameters. The highest concentration has the highest value $88.3 \pm 0.17)$ compared with the control $(4.67 \pm$ 0.14). The general fluctuation in values showed no direct relationship with the exposure concentration.

Haematological parameters have been associated with health indices and are of diagnostic significant in routine clinical evaluation of state of health (Inyang, 2008). Haematological and biochemical profile of blood can provide important information about the internal environment of the organism (Masogust, 2001). The changes observed in haemoglobin, PCV, WBC and Platelets showed a direct relationship with the exposure 
concentrations. Values increased with increasing concentration of the toxicant. Banace, (2008) reported that WBC may increase or decrease in certain diseases. The significant increase in WBC and haemoglobin are in line with the believe that since WBC functions in organisms against foreign production are aided by phagocytosis and antibody production, values will increase as a result of lethally effect of the toxicant (Inyang, 2008; Svobodova, 1971). Platelets are nucleated cells which are responsible for blood clotting in fish; slight decrease in values observed in this study may signify the effect on platelet (thrombocyte) production.

Lymphocytes and neutrophils form part of the granulocytes that make up leucocytes in animals. Values obtained here were not significant. There was no clear difference between the treatment groups and the control. This report is contrary to Svobodova (1971) which reported that carbon tetrachloride and benzene elicit excess glucocorticoid, antibody depression, retard the migration of phagocytic leucocytes and alteration of the total WBC count. The toxicant may not have damaged blood cells as observed in this study.

Table 1 Physico-Chemical Parameters of the Exposed Concentration of Paraquat dichloride

\begin{tabular}{|c|c|c|c|c|c|}
\hline $\begin{array}{c}\text { Conc. of Paraquat } \\
\text { dichloride }(\mathbf{p p m})\end{array}$ & $\begin{array}{c}\text { Alkalinity } \\
\mathbf{m g} / \mathbf{l}\end{array}$ & $\begin{array}{c}\text { Conductivity } \\
\boldsymbol{\mu s} / \mathbf{c m}\end{array}$ & $\mathbf{p H}$ & $\begin{array}{c}\text { Turbidity } \\
\text { NTU }\end{array}$ & $\begin{array}{c}\text { Dissolved Oxygen } \\
\mathbf{m g} / \mathbf{l}\end{array}$ \\
\hline 0.00 & $12.33 \pm 0.78$ & $99.50 \pm 21.46$ & $6.27 \pm 0.08$ & $0.25 \pm 0.45$ \\
\hline 0.10 & $12.40 \pm 0.84$ & $105.80 \pm 80.0$ & $6.37 \pm 0.07$ & $0.20 \pm 0.42$ \\
\hline 0.20 & $15.25 \pm 0.96$ & $108.75 \pm 20.76$ & $6.37 \pm 0.07$ & $0.50 \pm 0.7$ & $6.28 \pm 0.05$ \\
\hline 0.30 & $14.88 \pm 0.99$ & $136.12 \pm 14.04$ & $6.35 \pm 0.11$ & $0.50 \pm 0.58$ & $6.17 \pm 0.01$ \\
\hline 0.40 & $17.09 \pm 0.70$ & $128.00 \pm 16.36$ & $6.20 \pm 0.11$ & $0.18 \pm 0.40$ \\
\hline 0.50 & $13.67 \pm 1.56$ & $118.67 \pm 17.20$ & $6.23 \pm 0.01$ & $0.42 \pm 0.57$ & $5.35 \pm 0.03$ \\
\hline
\end{tabular}

Table 2 Haematological Responses of Clarias gariepinus exposed to various concentrations of paraquat

\begin{tabular}{|c|l|l|l|l|l|l|l|}
\hline $\begin{array}{c}\text { dichloride } \\
\begin{array}{c}\text { Conc. of } \\
\text { Paraquat } \\
\text { dichloride (ppm) }\end{array}\end{array}$ & $\begin{array}{l}\text { Hb } \\
(\mathbf{g} / \mathbf{1 0 0 m l})\end{array}$ & PCV $(\boldsymbol{\%})$ & $\begin{array}{l}\text { WBCx10 } \\
(\boldsymbol{\mu} / \mathbf{m m})\end{array}$ & NEU (\%) & Lym(\%) & ESR & $\begin{array}{l}\text { Platelets } \\
(\boldsymbol{\%})\end{array}$ \\
\hline 0.00 & $4.67 \pm 0.14$ & $14.7 \pm 0.005$ & $87.7 \pm 3.71$ & $14.3 \pm 0.17$ & $86.3 \pm 0.79$ & $8.55 \pm 2.0$ & $6.20 \pm 0.1$ \\
\hline 0.10 & $5.06 \pm 2.58$ & $14.0 \pm 0.00$ & $104.0 \pm 0.00$ & $10.0 \pm 2.23$ & $85.0 \pm 0.00$ & $8.40 \pm 0.0$ & $5.70 \pm 0.4$ \\
\hline 0.20 & $6.27 \pm 1.82$ & $19.3 \pm 0.17$ & $104.0 \pm 0.00$ & $13.7 \pm 2.24$ & $86.0 \pm 0.00$ & $7.50 \pm 0.1$ & $5.90 \pm 2.6$ \\
\hline 0.30 & $6.33 \pm 0.52$ & $23.3 \pm 0.44$ & $94.3 \pm 2.85$ & $12.3 \pm 0.17$ & $88.3 \pm 0.17$ & $7.95 \pm 2.1$ & $6.10 \pm 0.5$ \\
\hline 0.40 & $4.33 \pm 0.26$ & $15.0 \pm 0.77$ & $96.3 \pm 0.17$ & $9.00 \pm 1.82$ & $88.0 \pm 0.00$ & $8.23 \pm 3.1$ & $4.10 \pm 2.7$ \\
\hline 0.50 & $6.00 \pm 0.00$ & $19.7 \pm 0.17$ & $93.0 \pm 0.00$ & $11.7 \pm 0.17$ & $88.3 \pm 0.17$ & $8.60 \pm 0.0$ & $\mathbf{4 . 2 5} \pm 0.0$ \\
\hline
\end{tabular}

Haemoglobin (Hb), Packed cell volume (PCV), White blood cells (WBC), Neutrophilis (Neu), Lymphocyte (lym), Erythrocyte sedimentation rate (ESR)7

\section{Conclusion}

This study has shown that paraquat dichloride is toxic to Clarias gariepinus (adult) and that the toxicity varies with the duration of exposure. The low concentrations of paraquat dichloride that succeed unusual behaviour changes in Clarias gariepinus metabolism clearly showed the level of toxicity of paraquat dichloride on organisms. It can also be concluded that paraquat dichloride causes significant changes in haematological parameters of Clarias griepinus.

\section{References}

[1]. APHA (American Public Health Association), (2011). Standard Methods for Examination of Water and Wastewater. AHPA, Washington DC.

[2]. Atamanalp, M., Keles, M.S. and Aras, H.I. (2001) The Effects of Cypermethrin (a Synthetic Pyrethroid) on some Biochemical Parameters (Ca, $\mathrm{P}, \mathrm{Na}, \mathrm{Tp}$ ) on the Trout (Oncorhynchus myleiss). Canadian Journal of Fish and Aquatic Sci. Vol. 45 pp 219-222.

[3]. Blaxhall, P.C. and Daisley, K.W. (1973) Routine Haematological Methods for use with Fish Blood. Vol. 5, Issue 6, pp 771-781.

[4]. Bruton, M.N. (1979) The Breeding Biology and Early Life Development of Clarias gariepinus (Pisces: Claridae) in the Lake Sibaya, South Africa; Review of Breeding in species of subgenus Clarias. Zool. Soc. London. Trans. 35 (1) 145

[5]. Bus, A.S., Victor, P.S., Kingsley, G.B., Brikilia, S.S. and Vincent, N.O. (1983) Paraquat Model for Oxidant-Initiated Toxicity. Environmental Health Perspective. Vol. 55 pp 37-46.

[6]. Inyang, I.R. (2008) Haematological and Biochemical Responses of Clarias garipiepinus to Diazinon. PhD Thesis, Rivers State University of Science and Technology, Port Harcourt. Pp 126-131.

[7]. Mayer, F.L. and Ellersieck, M.R. (1986) Manual of Acute Toxicity, Interpretation and Database for 410 Chemicals and 65 species of Fresh Water Animals. Resource Publication No 160, Fish and Wildlife Service, United States Dept. Of Interior, Washington DC 3005 p

[8]. Svobodova, Z. (1971) Some Haematological and Metabolic Changes in Fish occurring after Pesticide Intoxication. Bull Vur Vodnany, Vol. 7 pp 27-36

[9]. Wahua, T.A.T., 1999. Applied Statistisc for Scientific Studies. Africa Link Books, Ibadan. 